\title{
SETE LECCIÓNS DA COVID
}

\author{
Armesto Ramón, Constantino
}

\section{INTRODUCIÓN}

O 11 de marzo de 2020, a Organización Mundial da Saúde (OMS) declara pandemia a infección causada polo SARS-CoV-2. Hoxe pode anunciarse que xamais na historia da ciencia houbo tanto coñecemento acumulado sobre un virus aos poucos meses de descubrirse; pero a epidemioloxía, como calquera ciencia, necesita tempo para repetir os experimentos e confirmar os resultados; o quefacer científico non é compatible coa présa dos medios de comunicación ou a urxente demanda de información por parte do público (1). Ademais, a epidemioloxía e a viroloxía corríxense continuamente (2), o que hai meses se dubidaba ou se ignoraba, hoxe sábese; talvez iso produza desconfianza nos profanos; pero os científicos saben que é o método correcto. Entre a abundante información sobre este virus en particular (3) e sobre os virus en xeral (4) vou seleccionar algúns resultados que talvez nos ilustren sobre o comportamento da natureza e os seus efectos sobre nós.

\section{1o Lección. Os virus poderían non estar vivos}

A cristalización é unha característica esencial dos minerais. Cristalizan os compostos iónicos, os metais, moléculas como a urea ou a vitamina $\mathrm{C}$ e tamén proteínas como a insulina e a hemoglobina. Sorpréndenos que os virus tamén cristalicen -demostrouno Wendell Stanley en 1935: por iso déronlle o Nobel de Química-; e fascínanos que os virus teñan fermosas formas helicoidais, de icosaedros, esferas ou outras máis complexas -segundo cal sexa o virus-, cada unha delas idéntica ás demais; propiedades que os separan da irregularidade dos organismos e achégaos á arquitectura dos minerais.

En ausencia de células os virus son seres inertes; lixeiros de equipaxe, co seu conciso material xenético empaquetado no interior dunha cápsula proteínica, esperan a achar unha célula onde 
ancorarse e transmitir os seus xenes porque, dunha maneira imprescindible, necesitan introducirse dentro das células para reproducirse. Tanto é así que a célula infectada proporciona ao virus o metabolismo enerxético (a enerxía), os bloques estruturais dos seus compoñentes (a materia) e a maquinaria para a síntese das súas moléculas.

Aínda que é evidente que para cualificar un ente como vivo (5) ou non, antes debe definirse un ser vivo, engado un terceiro argumento como proba da ausencia de vida dos virus: o seu mínimo tamaño. Aínda que os virus son algo maiores que as moléculas, son moi pequenos, entre trinta e trescentos nanómetros, tanto que nin poden verse co microscopio óptico, debe recorrerse ao microscopio electrónico para observar as diminutas partículas esféricas do coronavirus, cuxo diámetro (6) medio mide cento vinte e cinco nanómetros; compárense coas bacterias, cuxo tamaño oscila entre mil e tres mil nanómetros ou coas partículas de po (PM10, PM2.5) de dez mil ou dous mil cincocentos nanómetros.

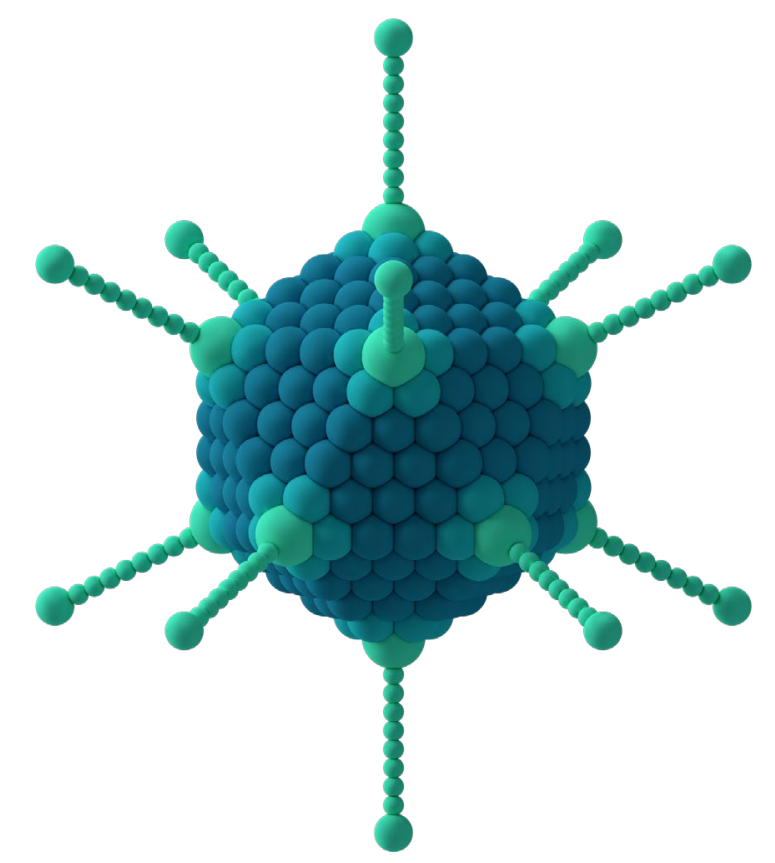

Figura 1. Adenovirus (Thomas Splettstoesser, Wikimedia Commons).

Xa sabemos que os virus SARS-CoV-2 transmítense da persoa enferma á persoa susceptible por vía aérea (6), a través das gotiñas (a maioría menores de dez micrómetros) que emitimos ao respirar, falar, tusir ou esbirrar. Agora ben, esas gotiñas de auga emitidas -que conteñen os viruspresentan un comportamento balístico ou ben se comportan como aerosois? Que significa iso? Se se axita un vaso de auga con po, ao deixalo en repouso, as partículas, insolubles e visibles, deposítanse no fondo; tal mestura é unha suspensión. Unha disolución de azucre posúe partículas de dimensións moleculares que non sedimentan ao deixalas en repouso. Entre unhas e outras existen mesturas -as dispersións coloidais- cuxas partículas son de tamaño intermedio; aínda así son o suficientemente pequenas para dispersarse homoxeneamente no medio, non sedimentar durante horas, días ou mesmo indefinidamente, e pasar a través de calquera filtro; chamamos aerosois a unha variedade delas, cando o medio dispersante é aire, como o fume do tabaco, a néboa ou as nubes. Retomo o fío do discurso sobre a transmisión dos coronavirus: se o tamaño da gota que contén o virus é menor de cen micrómetros considérase un aerosol, debido a que 
queda suspendido no aire por un tempo; se é maior, ten comportamento balístico: descende ao chan en poucos segundos por efecto da gravidade e percorre dous metros de distancia. Resulta entón que os aerosois non só interveñen no clima -serven como núcleos de condensación para a formación das nubes-, e na saúde -a OMS (2016) estima que a contaminación atmosférica provoca catro millóns douscentos mil defuncións anuais-, senón tamén na transmisión dos coronavirus. Que lle imos a facer!

\section{2ำ Lección. Os virus multiplícanse e evolucionan}

Cal é a composición dun virus? Material xenético (ARN ou ADN) protexido por unha envoltura de proteínas e, nalgúns casos, como os coronavirus, envolvida por unha membrana externa de lípidos. Resulta sorprendente que con tan poucos compoñentes non só sexa capaz de reproducirse, senón tamén obrigar á célula que o aloxa a sintetizar as súas proteínas; e como a automultiplicación (7) é unha propiedade das células, poderiamos argumentar que, desde este punto de vista, o virus está vivo. Poñamos números: cada virus pode facer entre dez mil e cen mil copias de si mesmo nunha única célula; por iso deducimos que a súa multiplicación é exponencial. Pescudar a composición do material xenético dun virus non é un asunto banal: pode afectarnos. A molécula de $\mathrm{ADN}$ é estable e a maquinaria celular revisa a súa correcta duplicación; a molécula de ARN é máis inestable e a maquinaria celular non revisa a súa correcta duplicación. En consecuencia, os virus ADN mutan pouco e os virus ARN mutan moito. O SARS- CoV-2, como virus ARN, muta moito; por tanto, a inmunidade adquirida por unha persoa pode perderse despois de certo tempo, como sucede co virus da gripe.

Ademais de ser as entidades biolóxicas máis abundantes da biosfera, os virus son extraordinariamente diversos: uns, como o poliovirus, teñen xenomas de ARN, outros, como o virus do herpes, de ADN; o xenoma da influenza é monocatenario, o da varíola bicatenario; tamén as súas estruturas e estratexias de reprodución son igualmente diversas. Por todo iso, a súa orixe resulta un tema fascinante: un dous por cento da secuencia xenómica separa os humanos dos chimpancés, diverxencia que tardou oito millóns de anos en concretarse; para cambiar o mesmo porcentaxe do seu xenoma, o dous por cento, os poliovirus tardan cinco días! Imaxínese o curioso lector o que poden facer os virus en millóns ou miles de millóns de anos; desgraciadamente non hai fósiles para comprobalo. Aínda que o tema está envolvido nun mar de conxecturas, os expertos debaten entre tres hipótese: quizais os virus fosen precursores da vida celular, talvez organismos previamente libres que se converteron en parasitos, seica elementos xenéticos que conseguiron a capacidade de moverse entre as células. A existencia de xenes compartidos por unha ampla variedade de virus, que faltan nos xenomas celulares, suxire un mundo antigo de virus; é posible que houbese un fluxo ininterrompido de xenes víricos desde a etapa precelular da vida ata os nosos días. Esta observación proporciona unha peza máis na imaxe do comezo da vida: talvez os virus orixináronse nunha etapa previa á existencia das células. 


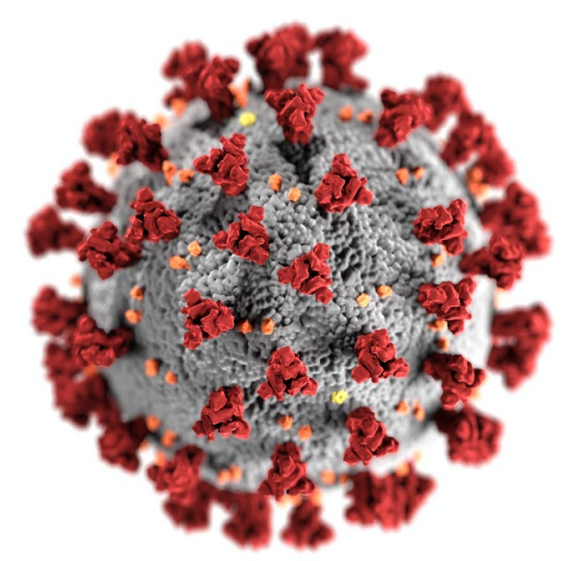

Figura 2. SARS-COV-2

Outro aspecto da historia da vida temperá refírese á formación das células animais e vexetais. Todas conteñen mitocondrias e as vexetais ademais, cloroplastos; trátase de orgánulos celulares que foron no seu momento bacterias independentes que estableceron unha relación simbiótica cunha célula orixinal (8). Participarían os virus en simbioses semellantes? Só hai dúas variedades de células na biosfera: unhas non conteñen núcleo e outras si. Preguntámonos como adquiriu o núcleo unha célula que carecía del, despois de todo, se iso non ocorrese, nós non existiriamos. Conxectúrase que o núcleo celular evolucionou dun virus de ADN: o virus estableceuse dentro dunha arquea e evolucionou a núcleo mediante a adquisición de xenes do hóspede. Por regra xeral, os microorganismos atrapados morren e degrádanse; ás veces, escapan á destrución e continúan danando aos seus captadores ata provocarlles a morte. Nalgunha rara ocasión, ambos sobreviven nun estado de mutua tolerancia, que pode tornarse despois en asistencia recíproca e, por último, en dependencia. A teoría viuse apoiada polo descubrimento de virus xigantes (9) de ADN (Mimivirus) que, en lugar de reproducirse e destruír ao hóspede, tomarían o control da arquea e se converterían en núcleo: o virus secuestraría á célula para asegurar a súa supervivencia. Probas? Suponse que algunhas características do núcleo derivan da súa ascendencia viral: o virus aseméllase ao núcleo celular (ADN lineal dentro dunha membrana de lípidos).

\section{3ํㅡㄴㅡón. Non tódolos virus son malos: os fagos}

O mundo dos virus está aínda sen descubrir. Acháronse, non fai moito (2016), oitenta e cinco mil secuencias virais: compárense coas tres mil descritas. Certo, existen moitos virus no noso planeta, estímase que dez quintillóns; realmente trátanse das entidades biolóxicas terrestres máis abundantes; aínda así, identificar aos virus no ambiente é complicado porque se cultivaron menos do un por cento; con todo, as análises metaxenómicos mostran que as comunidades virais existentes son extraordinariamente diversas: probablemente hai cinco mil xenotipos virais diferentes en cada douscentos litros de auga de mar e un millón nun quilogramo de sedimento mariño. Desgraciadamente case todos os coñecementos que temos dos virus refírense aos patóxenos; por iso ninguén debe alarmarse pola aparente abundancia dos virus que producen enfermidades: hepatite, dengue, poliomielite, arrefriado, rubéola, febres hemorráxicas, 
sarampelo, parotidite, rabia, gripe, varicela, herpes zóster, herpes, mononucleose infecciosa, vexigas, cancro cervical, gastroenterite infantil, SARS, febre amarela, virus do Nilo Occidental, sida e Covid-19 porque non todos os virus, nin moito menos, son daniños para nós, só unha mínima proporción, moitos, a maioría, reprodúcense sen causar dano ao organismo infectado; e non nos prexudican porque, sendo parasitos, requiren a supervivencia do organismo que os hospeda para asegurar a súa propia supervivencia. Así o observaron os virólogos: cando un virus se multiplica no seu hóspede natural, ou non causa enfermidade nel ou a enfermidade é leve na maioría dos casos. Os virus adoitan producir trastornos graves cando infectan organismos diferentes aos naturais; este feito suxire que boa parte dos virus asociados ás enfermidades están en proceso de adaptación e que, unha vez lograda esta, a estratexia viral consistirá en propagarse sen afectar ao organismo onde se aloxa. Xorde unha conclusión obvia destes descubrimentos. Coidado coa invasión dos ecosistemas non humanizados ou co contacto coa fauna salvaxe, porque poderían contaxiarnos os seus virus! (10) Preveñámonos dos morcegos (11), reservas de virus (tamén do SARS-CoV-2), ou dos insectos hematófagos, que chupan sangue; e lembremos, ao visitar certos hábitats, que algúns virus non precisan de vectores de transmisión porque se propagan polo aire, ou pola inxestión de auga ou alimentos infectados.

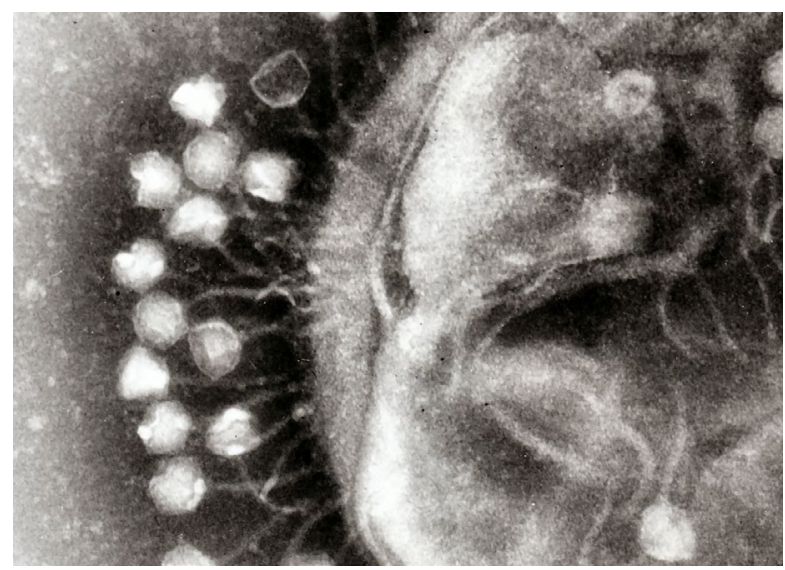

Figura 3. Fagos (Graham Beards, Wikimedia Commons).

Durante a 1a Guerra Mundial as autoridades sanitarias europeas encargaron a Félix d' Herelle remediar a epidemia de disentería que afectaba os combatentes. Deixo que o propio científico relate o seu eficaz traballo "A mañá seguinte... experimentei un deses momentos de intensa emoción que compensan ao investigador de todas as súas penas... todas as bacterias [Shigella, causantes da enfermidade] desapareceran... foi tal a miña emoción que de súpeto o comprendín: o que causaba as manchas claras era de feito un microbio, un virus filtrable, pero un virus que era parasito das bacterias". O investigador descubrira os fagos (ou bacteriófagos), virus que destrúen bacterias. En 1919, administrou fagos a un neno afectado de disentería: curouno, nada máis hai que engadir. Estimulado polo éxito, Félix d' Herelle promoveu a terapia antibacteriana con fagos obtendo resultados ambiguos: mentres que a antiga Unión Soviética e a India empregárona, o resto do mundo preferiu os antibióticos. Por que non usamos agora a terapia con fagos? Transcribirei, a continuación, as vantaxes e inconvenientes da fagoterapia (12) para que o cauto lector xulgue. Facilidades dos fagos: rompen as bacterias resistentes aos antibióticos; son específicos, e por tanto non danan a biota do paciente; non xeran reacción cos anticorpos; o tratamento pode ser preventivo; e, en moitos casos, requírese unha dose única de fagos para 
diminuír a infección. Reparos aos fagos: son específicos, e por tanto o seu ámbito de acción é limitado; poden producir niveis altos de endotoxinas en infeccións causadas por bacterias Gramnegativas; son eliminados rapidamente polo sistema inmune; é difícil fabricar fármacos sólidos; é difícil proporcionar fagos; e resulta complicado rexistrar a propiedade intelectual. Tendo presente que a fagoterapia reduce, pero non elimina as bacterias, cabe sinalar que os bacteriófagos xa se aplicaron no tratamento de infeccións bacterianas de Pseudomonas, Staphylococcus, Escherichia e Mycobacterium, resistentes a antibióticos, con diferentes graos de eficacia que van desde o setenta e cinco por cento ao cento por cento.

Figura 4. Felix D’Herelle

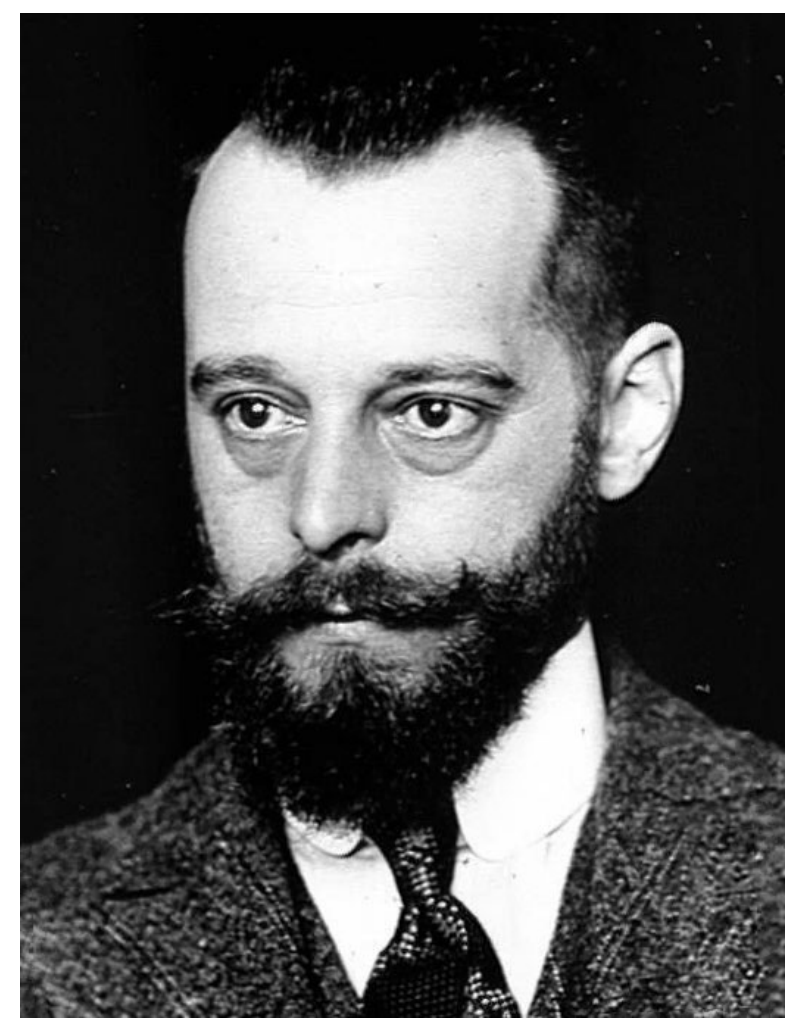

Quen foi Félix d' Herelle (13), pioneiro da guerra antimicrobiana e descubridor dos fagos? Necesitaríase un libro para contar a aventureira vida do intrépido investigador canadense que chegou ao mundo en 1873. Tratarei de resumila en contados parágrafos. En 1911, anunciou a detención dunha praga mexicana de lagosta: fíxoo infectando os insectos con bacterias patóxenas extraídas das propias lagostas. En 1917, anunciou o descubrimento dun microbio antagónico do bacilo da disentería; tratábase dun virus que infecta as bacterias, que chamou fago. En 1919, erradicou unha praga de tifo do pito con fagos; tras o éxito, curou con fagos a un paciente humano de disentería: a fagoterapia converteuse entón nunha arma contra as enfermidades bacterianas. En 1926 foi candidato ao premio Nobel: non llo concederon debido aos seus moitos detractores; quizais pola incerteza que envolvía a terapia con fagos, quizais porque o investigador utilizábaos sen precaución. Non importa, en Exipto, impediu que o cólera se propagase a Europa; na India, dividiu por sete o número de mortos pola enfermidade. Fallos frecuentes na terapia debido á incorrecta produción de fagos ou a diagnósticos erróneos (os fagos son moi específicos) 
provocaron que a comunidade científica rexeitase o novo tratamento. En 1934 é recibido como un heroe en Xeorxia (URSS); vai establecerse alí porque admira ao comunismo (dedicou un dos seus libros a Stalin) e porque quere traballar co seu amigo o profesor xeorxiano George Eliava; pero o seu amigo e o xefe da policía soviética en Xeorxia namoráronse da mesma muller: Eliava foi executado e d' Herelle fuxiu para salvarse. Durante a Segunda Guerra Mundial, mentres permanece baixo arresto domiciliario en Francia (faleceu en París en 1949), a fagoterapia contribuíu a curar infeccións nas tropas de ámbolos dous bandos. Acabada a guerra, a penicilina converteuse no axente antibacteriano máis utilizado, porque era máis fiable e fácil de usar que a fagoterapia, a pesar dos seus efectos secundarios e das bacterias resistentes. Regresará algunha vez, depurados os seus inconvenientes, o tratamento con bacteriófagos? $(14,15,16)$

Aínda non somos conscientes do papel que xogan os virus no mantemento da vida. Fixémonos nos fagos, que constitúen a maioría dos virus existentes no planeta; son os maiores depredadores de bacterias, se desaparecesen alteraríanse os ecosistemas oceánicos, onde o noventa por cento da vida é microbiana, e perturbaríanse probablemente outros moitos ecosistemas terrestres. Os virus matan, cada día, preto da quinta parte dos microbios oceánicos e preto da metade das bacterias oceánicas; aseguran así que o plancto teña suficientes nutrientes para levar a cabo a imprescindible fotosíntese mariña que produce preto da metade do osíxeno do planeta.

Hai outra maneira na que os virus interveñen na biosfera. Todos os organismos que poden ser infectados por virus teñen a oportunidade de absorber o seu xenes e usalos ao seu favor, porque a inserción de novo ADN nos xenomas é evolución. E iso tamén afecta á nosa especie, pois os virus axudáronnos a converternos no que somos; sabemos que os elementos virais representan aproximadamente o oito por cento do xenoma humano e que o código viral adoita manifestarse como zonas inertes de $\mathrm{ADN}$, pero ás veces cumpre novas e útiles funcións. Citemos algunha: a duración do embarazo (17) está estritamente regulada para garantir o éxito reprodutivo; pois ben unha inserción retroviral (18) no xenoma intervén no control do instante do nacemento. No século XX poucos científicos coñecían a existencia do viroma humano; hoxe contemplamos aos trescentos oitenta billóns de virus que albergamos, como unha parte do conxunto de microorganismos que colonizan todos os recunchos do noso corpo; en realidade calquera de nós é un superorganismo onde cohabitan células, bacterias e virus, os mais abundantes de todos. Os últimos recontos indican que... ata a metade da materia biolóxica do noso corpo non sería humana! (19)

\section{4ª Lección. Esta pandemia non é a primeira nin será a última.}

\section{Sobre a mala memoria}

Ao longo da historia os virus cobráronse moitas vidas humanas; a actual pandemia de Covid-19 (20) é só un dos múltiples ataques virais que se produciron no século XXI, como o SARS, o Ébola e o Zica; sen esquecer os que sucederon no século XX, desde a pandemia de gripe de 1918 (21) que matou entre cincuenta e cen millóns de persoas, ata os douscentos millóns de óbitos causados pola varíola, aos que hai que engadir os sufrimentos debidos a poliomielite e o VIH. A lista de pandemias que nos afectaron é ampla: as bacterias da peste, tifo, difteria, sífile ou cólera causaron algunhas, outras os virus das varíola, sarampelo, poliomielite, febre amarela ou dengue, e unha das peores, o paludismo (ou malaria), nin uns nin outras. Mentres os nosos antepasados foron nómades apenas había posibilidade de contaxio, pero cando empezaron a concentrarse en aldeas e cidades comezaron os perigos; e se na sociedade contemporánea non hai fronteiras para as 
persoas, tampouco as hai para as enfermidades. De onde proceden? A maioría adoitan ser infeccións nos animais que se transmiten aos humanos.

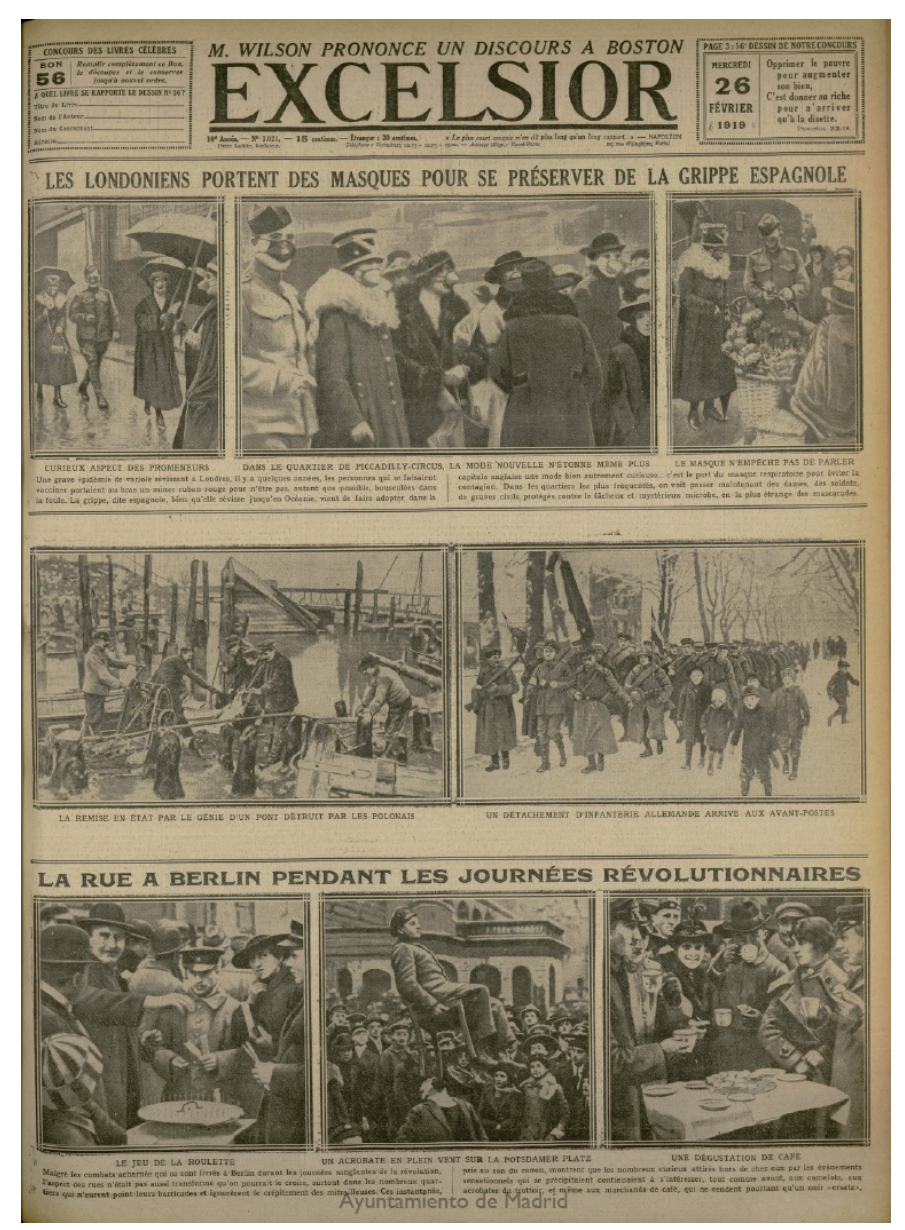

Figura 5. Gripe española de 1918.

Lembremos tres das pandemias máis mortais. A praga de Xustiniano, probablemente a peste bubónica causada pola bacteria Yersinia pestis, declarouse en Exipto no ano 541; propagouse pola conca do Mediterráneo, e de aí estendeuse a Europa, Persia e Etiopía: exterminou entre a oitava e a cuarta parte da poboación mundial. No século XIV, a peste negra, causada pola bacteria Yersinia pestis, afectou a Europa -faleceu un terzo da súa poboación- e Asia e terminou coa vida de oitenta millóns de persoas. Cando Cristóbal Colón e os seus acompañantes chegaron a América levaban consigo axentes patóxenos (o virus da varíola entre outros) aos que eran inmunes; pero non os nativos americanos: faleceron cincuenta millóns.

Coñecer a historia permítenos, ás veces, evitar tráxicos erros que cometeron os nosos antepasados; por exemplo, convén saber que non todas as epidemias convértense en pandemias. No ano 1911, unha epidemia de peste pulmonar (causada por bacterias) arrasou o nordés de China onde ocasionou máis de sesenta mil falecidos. Sospeitábase que a súa orixe era o comercio de animais salvaxes (marmotas). Para reducir a taxa de infección fixéronse confinamentos, 
corentena, usáronse máscaras, houbo restricións nas viaxes e controis fronteirizos. A ameaza de converterse en pandemia non se materializou.

A globalización non ten a culpa desta pandemia: antes houbo outras. Durante a Idade Media, a peste chegou de China á Gran Bretaña en pouco máis dun decenio, a pesar de que a poboación viaxaba en barcos de vela, cabalos ou a pé. A gripe rusa (alí identificouse por primeiro vez) de 1889 foi a primeira pandemia da era microbiolóxica que -estímase- matou a un millón de persoas; a rapidez da súa extensión foi asombrosa: tardou apenas seis semanas en estenderse por Europa e outras seis en facelo por todo o mundo. Tamén naquela época, o fracaso da medicina convencional, que ignoraba como abordar a enfermidade, propiciou que xente sen escrúpulos vendese pílulas e remedios que, nalgúns casos, resultaban peores que a enfermidade.

Tres leccións distintas ofrécenos o mesmo virus en tres conxunturas diferentes. Caso 1: En 1801, Bonaparte enviou unha expedición militar á Española (hoxe República Dominicana e Haití) para reprimir unha revolución de escravos: fracasou. Haití foi a primeira nación que proclamou a súa independencia (1804) en Iberoamérica despois de derrotar a un exército colonial, aínda que cabe engadir que tivo unha axuda fundamental, o virus da febre amarela matou á maioría dos franceses: oito de cada dez soldados, dunha forza que oscilou entre os sesenta mil e oitenta e cinco homes, perderon a vida. Caso 2: Nova Orleans (23), no século XIX, non só era un centro da escravitude e algodón, senón tamén era unha inmensa necrópole, onde a febre amarela mataba ao redor o oito por cento da súa poboación: máis de cento cincuenta mil de 1803 a 1861 . Con escasa infraestrutura de saúde pública, a única protección consistía en sobrevivir á enfermidade. As epidemias repetidas xeraron unha xerarquía mediante a cal os sobreviventes aproveitaron a súa inmunidade para exercer o poder social, económico e político sobre os non inmunizados. A inmunización demostraba que só quen asumise e superase un risco calculado era digno de investimento e podía buscar un emprego, un ascenso ou un préstamo bancario. Ademais, se os poderosos xa estaban inmunizados, para que preocuparse pola saúde dos febles non inmunizados? Caso 3: Ata o ano 1900, a febre amarela era unha terrorífica praga para quen vivía nunha cidade americana. Cando montóns de habitantes dunha cidade do Caribe ou dos Estados Unidos comezaban a volverse amarelos e a ter vómito negro, había que marchar da urbe maldita. Non existía outro remedio ata que un investigador, Walter Reed (22), probou que a hipótese proposta por Carlos Finlay era certa: un mosquito era o transmisor do axente infeccioso (un virus): eliminouse o mosquito, desapareceu a enfermidade.

Haberá no futuro novas pragas e novas pandemias; non se trata de se, senón de cando.

\section{5o Lección. Existen produtos químicos que destrúen os virus}

Algúns virus, concretamente os SARS-CoV-2, poden destruírse cunha acción moi sinxela: lavándose as mans con xabón! Si, repito, con só lavarse as mans con xabón. Por que cunha acción tan sinxela elimina o perigo? Os coronavirus teñen unha envoltura de lípidos que son graxas. 0 xabón disolve a envoltura viral, as biomoléculas compoñentes sepáranse e o virus desactívase, metaforicamente morre. Xa está! Perigo eliminado! Con só xabón en vinte segundos eliminouse a ameaza á nosa saúde! 0 ideal sería lavarse as mans con auga e xabón, pero como non sempre dispoñemos dun lavabo onde facelo, debemos recorrer a outros métodos que recomenda a Organización Mundial da Saúde (24): alcol etílico diluído ao setenta por cento ou auga osixenada (peróxido de hidróxeno) ao tres por cento (dez volumes).

Ademais das mans hai outros obxectos e superficies que, nalgún momento, desexariamos desinfectar. Como facelo? Tanto a Organización Mundial da Saúde (25) como o ministerio de Sanidade (26) recomendan o uso de hipoclorito sódico (a lixivia) como desinfectante pola súa 
intensa actividade bactericida e viricida, nunha concentración de substancia activa dunha décima por cento (mil ppm); comprobe a concentración do produto comprado, entre tres e cinco por cento (33,3 g/L a 55,5 g/L), quen a manexe, porque ha de diluíla para obter a concentración requirida. E se queremos comer verdura crúa? Mergulle os alimentos en auga potable á que engade un pouco de lixivia na cantidade que recomenda o Ministerio de Sanidade (27) para conseguir a desinfección.

Facer potable a auga é outro uso da lixivia que resolve un dos problemas máis indispensables de toda comunidade humana. A auga que bebemos debe estar libre de xermes patóxenos xa que se comprobou que moitas epidemias e enfermidades infecciosas (gastroenterite, salmonelose, disentería, hepatite ou poliomielite) proveñen do uso de auga contaminada. En Londres, en 1854, atribuíuse por primeira vez unha epidemia -de cólera- á auga infectada; moitas outras lle seguiron, o cólera en Hamburgo (1892-93), o tifo en Lausana (1862) e Barcelona (1914-15). Uns datos da OMS (28) axúdannos a cuantificar o problema, aínda que sete de cada dez humanos contemporáneos utiliza un servizo de subministración de auga potable xestionado de forma segura, dous mil millóns de persoas abastécense de auga contaminada por feces; e considérese que só a contaminación da auga para beber provoca máis de medio millón de mortes anuais por diarrea. As cidades sempre se localizan preto de lagos e ríos de onde obteñen a auga; e cando estes non existen aprovéitase a auga subterránea que se extrae mediante pozos ou se transporta: lémbrense os acuedutos romanos. Con todo, a auga non sempre é potable; afortunadamente os químicos resolveron o problema, e potabilizar a auga salvou máis vidas aínda que o descubrimento dos antibióticos ou a invención das vacinas. Un dato para calibrar a magnitude do éxito científico obtido. Só nunha cidade, Detroit, e nun ano: douscentos corenta e cinco mortes por millón debido ao tifo, antes da purificación da auga para a bebida (ano 1911); dúas defuncións despois (ano 1937). Ata finais do século XX a maioría das plantas potabilizadoras de auga en España empregaban a cloración, a miúdo con hipoclorito sódico como desinfectante; sen embargo, a presenza de compostos orgánicos na auga e a súa fácil reacción co cloro, formando subprodutos (halocarburos) potencialmente perigosos para a saúde, obrigou aos responsables das subministracións de auga potable a buscar novos axentes desinfectantes.

Os virus non só se destrúen no exterior, tamén queremos destruílos dentro do organismo; e non é necesaria a inxestión dalgún produto con cloro que pode resultar mortal (aínda que o recomende algún gobernante). Os antibióticos non se identificaron ata o século XX; trátase de axentes antibacterianos relativamente recentes cuxo uso non se xeneralizou ata a quinta década do século pasado. Agora ben, se os antibióticos non afectan aos virus, por qué non se fabrican antivirais? (29) Ata os anos oitenta do século XX os coñecementos sobre viroloxía non permitiron o seu desenvolvemento; por iso non hai suficiente variedade deles; con todo, sintetizáronse algúns, como os antivirais (30) contra os virus da gripe, do herpes e contra o VIH; e a maioría, igual que os antibióticos, son específicos de cada virus (ou familia deles). Existen xa antivirais contra os SARS-CoV-2? (31) A procura de antivirais contra os coronavirus non comezou este ano, nin o anterior; nun artigo publicado no 2004 pode lerse "Estes resultados suxiren que este composto ten potencial terapéutico para o control da infección do coronavirus" (32).

\section{Lección. A Covid curou un cancro: inmunoterapias e outras terapias}

Ano 2020. A un home de sesenta e un anos diagnosticóuselle un linfoma de Hodgkin en estadio III. Pouco despois diagnosticóuselle tamén pneumonía por SARS-CoV-2. Catro meses máis tarde o paciente presentou unha remisión xeralizada do linfoma. A explicación é que a infección vírica desencadeou unha resposta inmunitaria antitumoral que lle curou o linfoma (33). Non, non se sorprenda o lector porque non se trata dun caso excepcional: a inmunoterapia contra o cancro, a 
ciencia de mobilizar o sistema inmunolóxico propio para matar o cancro, nos últimos anos, detectou respostas clínicas sen precedentes: hai pacientes con cancro terminal que logran remisións completas (34). E aínda podemos avanzar un paso máis, por que non imitar ao sistema inmune e usar virus no canto de linfocitos para destruír células? Por que non converter aos virus en mísiles capaces de recoñecer, infectar e matar as células malignas sen alterar as células sas? (35). Esta viroterapia xa se experimentou con éxito en animais e espérase que sexa menos tóxica e máis eficiente.

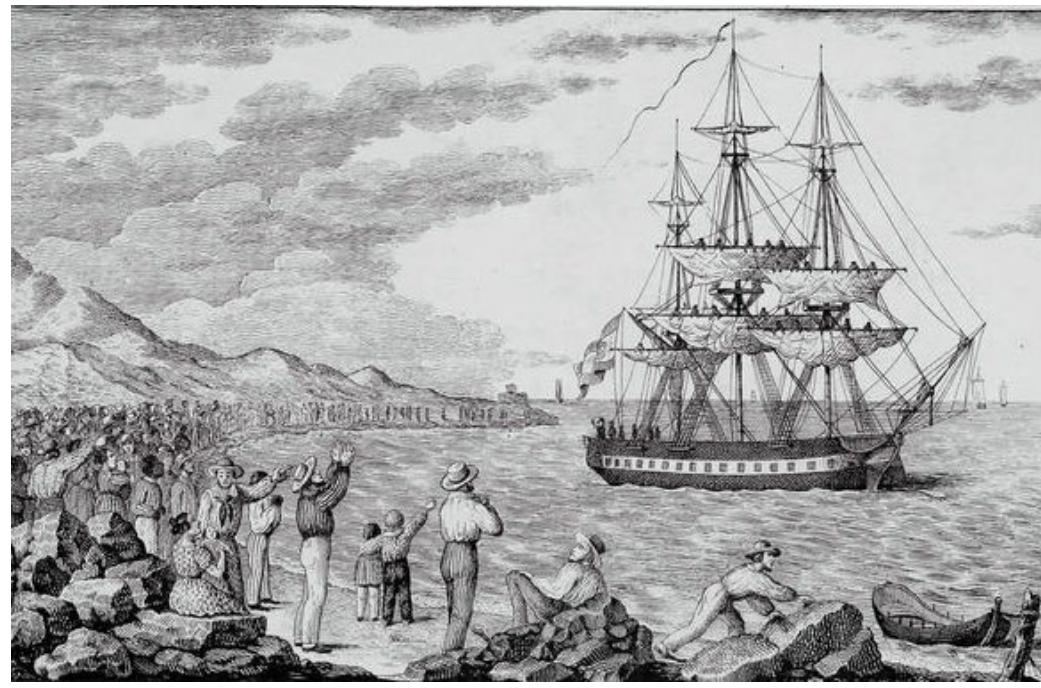

Figura 6. Corveta María Pita (Expedición da vacina).

Existen outras inmunoterapias máis habituais e probadas: refírome á inmunoterapia antiinfecciosa. A vacinación é unha das formas máis eficaces de evitar enfermidades: actualmente prevén de dous a tres millóns de mortes ao ano, e outro millón e medio podería evitarse se se mellorase a cobertura mundial das vacinas. Pode discutirse a necesidade ou non da vacina contra a gripe en adultos sans de mediana idade; pero non é discutible a necesidade da vacina contra graves enfermidades como a polio, difteria, tose ferina e outras: a vacina contra esas enfermidades salva e salvou vidas. É habitual que, nun ano, en España, o virus da gripe mate unhas seis mil persoas: no mesmo tempo a Covid mata dez veces máis: a vacina contra o SARS-CoV-2 tamén salvará vidas, millóns de vidas: pénsese na porcentaxe de anciáns que mata o coronavirus e que existen setecentos millóns de anciáns no mundo. Os virus das vexigas son unha das creacións máis insidiosas da natureza: pois matan, mataban, a unha de cada tres persoas infectadas. Grazas á vacina erradicouse a terrible enfermidade da face da Terra no 1980, e os españois contribuímos dunha maneira fundamental á súa extinción. Francisco Javier Balmis, digno sucesor de Bartolomé de las Casas, encabezou a primeira expedición sanitaria internacional da historia. 0 seu obxectivo? Que a vacina das vexigas alcanzase todos os recunchos do imperio español. América, Filipinas e tamén rexións de China beneficiáronse da épica viaxe, que durou desde 1803 ata 1806, e salvou a vida de millóns de nenos. E non me esquezo dos heroicos portadores da vacina: vinte e dous infantes, a maioría coruñeses, levárona nos seus corpos: non había outra maneira. Non unha, nin dous, nin tres... nin mil, nin dous mil, nin tres mil... nin un millón, nin dous millóns, nin tres millóns... centenares de millóns de vítimas salvou a vacina contra as vexigas, unicamente no século XX, e só cuantificamos unha enfermidade. Aínda que a 
varíola pode desaparecer (os humanos xa deixamos de vacinarnos contra ela) o seu primo vírico, as vexigas do simio está a preparar o seu regreso (36). Atención!

\section{7ª Lección. A superstición non é sinónimo da ignorancia.}

\section{Reivindicación do noso ilustre paisano Benito Feijoo}

Sen dúbida Isaac Asimov ou Carl Sagan divulgaron a ciencia e combateron con eficacia a ignorancia científica e a superstición dos seus contemporáneos; pero non é necesario evocar ilustres membros doutra cultura para inspirarnos. Benito Feijoo, eminente galego e o máis brillante literato da Ilustración española, publicou máis dun centenar de discursos entre 1726 e 1739. Os temas son diversos, pero en todos está presente o afán de erradicar a superstición e o empeño en divulgar a ciencia. Tomando como únicos xuíces as observacións e a razón, o ilustre erudito criticou as ideas irracionais, denunciou aos curandeiros e reprobou a astroloxía. Tres séculos escasos despois, avanzamos no camiño da racionalidade, pero moito menos do que algúns desexariamos.

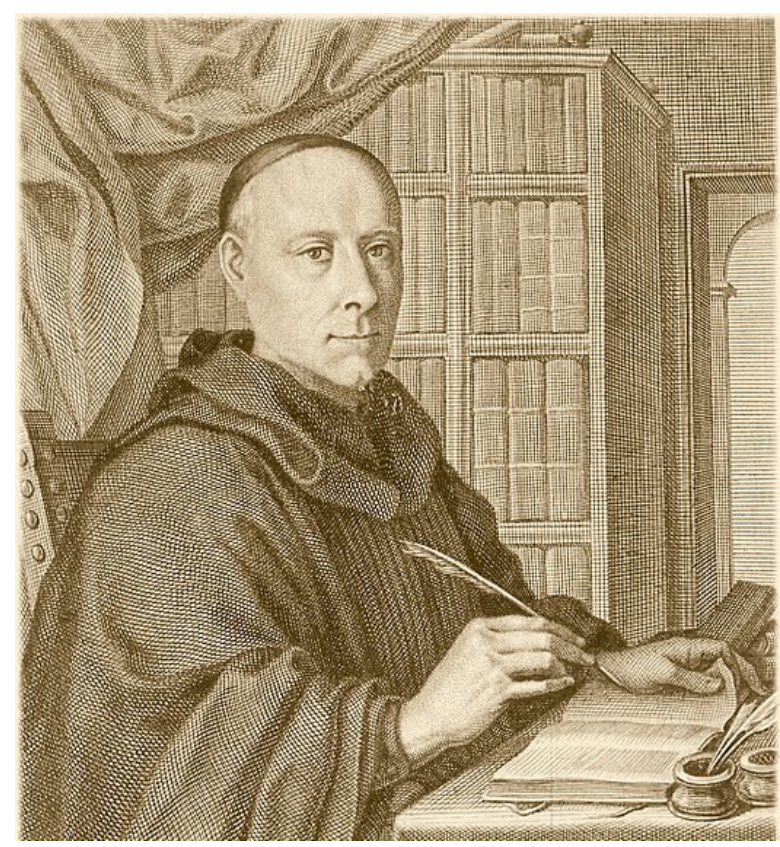

Figura 7. Benito Feijoo.

Moitas persoas non creron que os humanos chegaron á Lúa en 1969. Os escépticos sobre a evolución biolóxica e o cambio climático antrópico abundan. Existen persoas que negan a eficacia do cinto de seguridade nos vehículos. Steve Jobs, cofundador de Apple, recorreu á superstición no canto de á medicina para tratar o cancro: o cancro matouno; como el, moitos cren en pseudoterapias, como a homeopatía e outras semellantes. Non debe sorprendernos que un sector minoritario da poboación e algún médico confuso negue a eficacia das vacinas contra toda evidencia científica. A Organización Mundial da Saúde (37) identificou dez ameazas que debe abordar para mellorar a saúde da poboación humana mundial: o rexeitamento das vacinas é unha delas, igual que a resistencia aos antibióticos, o virus do Ébola, o dengue, o VIH, a contaminación 
do aire e o cambio climático. Se esta actitude débese á ignorancia, a educación pode corrixila; pero se os crentes na ineficacia das vacinas son persoas formadas, hai algo que podamos facer?

\section{REFERENCIAS}

1. López-Goñi, Ignacio (2020): “El coronavirus más mediático”, Investigación y ciencia, nº. 523, pp. 12-14, abril.

2. Smith, George Davey; Blastland, Michael; Munafò, Marcus (2020): “Covid-19's known unknowns". British Medical Journal. https://doi.org/10.1136/bmj.m3979 (19 October).

3. Fischetti, Mark (2020): “Dentro del nuevo coronavirus”. Investigación y ciencia, n⿳. 526, pp. 44-49, julio.

4. Pallas Benet, Vicente (2007): “En el límite de la vida. Un siglo de virus”. La Voz de Galicia.

5. Villarreal, Luis P. (2005): “'Tienen vida los virus?”. Investigación y ciencia, no. 341, pp. 54-59, febrero.

6. Ministerio de sanidad (2021). "Información científica-técnica. Enfermedad por coronavirus, COVID-19". https://www.mscbs.gob.es/profesionales/saludPublica/ccayes/alertasActual/nCov/docu mentos/ITCoronavirus.pdf .

7. Nelson, David; Cox, Michael (2019): “Lehninger. Principios de Bioquímica”. Séptima Edición. Ed. Omega. España.

8. Duve, Christian de (1996): “El origen de las células eucariotas". Investigación y ciencia, noo. 237, pp.18-26, junio.

9. Etten, James L. Van (2012): “Virus gigantes”. Investigación y ciencia, no. 424, pp.68-74, enero.

10. Robinson, Nicholas; Walzer, Christian (2020): "Cómo evitar una nueva pandemia". Investigación y ciencia, no. 524, pp. 47, mayo.

11. Qiu, Jane (2020): “Perseguir a los coronavirus”. Investigación y ciencia, no. 525, pp. 20-26, junio.

12. Segundo A., Nallelyt; Hernández B., Efrén; López V., Oliver; Torres A., Oscar (2010): “Los bacteriófagos como una alternativa en el tratamiento de enfermedades infecciosas bacterianas (Fagoterapia)". Revista Mexicana de Ciencias Farmacéuticas, vol. 41, núm. 3, julio-septiembre, 2010, pp. 17-26. https://www.redalyc.org/pdf/579/57916078003.pdf .

13. Pallas, Vicente (2015): “Presentación. 100 Años de bacteriófagos”. Virología, vol. 18 n‥ 3, pp. 3-6.

14. Schmidt, Charles (2020): “¿Vuelve la fagoterapia para quedarse?”, Investigación y ciencia, n⿳0. 522 , pp. 74-81, marzo.

15. Rohwer, Forest; Segall, Anca (2016): “Un siglo de bacteriófagos”, Investigación y ciencia, nº. 475 , pp. 54-55, abril.

16. Fernández Llamas, Lucía; Gutiérrez, Diana; García, Pilar (2017): “Los bacteriófagos, unos eficaces antimicrobianos", Investigación y ciencia, nํ․ 486, pp. 16-17, marzo. 
17. Chuong, Edward B. (2018): “The placenta goes viral: Retroviruses control gene expression in pregnancy". Plos Biology. October 9, 2018. https://doi.org/10.1371/journal.pbio.3000028.

18. Dunn-Fletcher, Caitlin E. et al. (2018): "Anthropoid primate-specific retroviral element THE1B controls expression of CRH in placenta and alters gestation length". Plos Biology. September 19, 2018. https://doi.org/10.1371/journal.pbio.2006337.

19. Pride, David (2021): “Los virus de nuestro cuerpo”. Investigación y ciencia, no. 533, pp. 7683, febrero.

20. McKenna, Maryn (2020): “El retorno de las epidemias”. Investigación y ciencia, no. 530, pp. 46-51, noviembre.

21. Taubenberger, Jeffery K.; Reid, Ann H.; Fanning, Thomas G. (2005): "El virus de la gripe de 1918". Investigación y ciencia, ํo. 342, pp. 44-53, marzo.

22. Kruif, Paul de (1986): "Cazadores de microbios". Salvat, Barcelona.

23. Olivarius, Kathryn (2019): "Immunity, Capital, and Power in Antebellum New Orleans". The American Historical Review, Volume 124, Issue 2, April 2019, Pages 425-455, https://doi.org/10.1093/ahr/rhz176.

24. OMS (2012): "Formulaciones recomendadas por la OMS para la desinfección de las manos":https://www.who.int/gpsc/5may/tools/ES_PSP_GPSC1_GuiaParaLaElaboracionLo calWEB-2012.pdf.

25. OMS (2020): "Cleaning and disinfection of environmental surfaces in the context of COVID19". 16 May 2020. I COVID-19: Infection prevention and control / WASH. https://www.who.int/publications/i/item/cleaning-and-disinfection-of-environmentalsurfaces-inthe-context-of-covid-19.

26. Ministerio Sanidad: https://www.mscbs.gob.es/profesionales/saludPublica/ccayes/ alertasActual/nCov/documentos/Medidas higienicas COVID-19.pdf

27. Ministerio de Sanidad. "Frutas y verduras siempre seguras". https://www.mscbs.gob.es/consumo/pec/recomendacion/frutasVerduras.htm

28. OMS (2019): "Agua". 14 de junio de 2019. https://www.who.int/es/news-room/factsheets/detail/drinking-water.

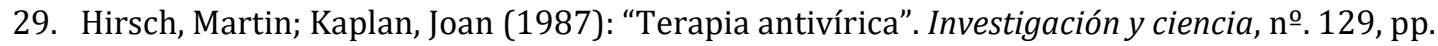
50-62, junio.

30. Haseltine, William (2002): “Fármacos contra virus”. Investigación y ciencia, no. 304, pp. 1623, enero.

31. Haseltine, William (2020): “Del sida a la covid-19”. Investigación y ciencia, no. 531, pp. 36-42, diciembre.

32. Neuman, B.W. et al. (2004): "Antisense morpholino-oligomers directed against the 5' end of the genome inhibit coronavirus proliferation and growth". Journal of Virology, june.

33. Sarah Challenor, David Tucker (2021): "SARS-CoV-2-induced remission of Hodgkin lymphoma". British Journal of Haematology. 02 January 2021. https://doi.org/10.1111/bjh.17116. 
34. Kelly, Priscilla N. (2018): “The Cancer Immunotherapy Revolution”. Science, 23 Mar 2018: Vol. 359, Issue 6382, pp. 1344-1345. DOI: 10.1126/science.359.6382.1344.

35. Nettelbeck, Dirk M.; Curiel, David T. (2004): "Vectores víricos antitumorales". Investigación y ciencia, no. 328, pp. 76-83, enero.

36. Shah, Sonia (2013): “La nueva amenaza de los poxvirus”. Investigación y ciencia, no .440 , pp. 32-37, mayo.

37. OMS (2019): https://web.archive.org/web/20200821130457if_/https://www.who.int/es/ news-room/feature-stories/ten-threats-to-global-health-in-2019. 